\title{
Delivery and breastfeeding in pregnant patients with COVID-19 (Review)
}

\author{
MIHAI CRISTIAN DUMITRASCU ${ }^{1,4 *}$, MONICA MIHAELA CIRSTOIU ${ }^{1,4 *}$, ADINA-ELENA NENCIU ${ }^{4 *}$, \\ AIDA PETCA $^{1,5}$, FLORICA SANDRU ${ }^{3,6}$, RAZVAN-COSMIN PETCA $^{2,7}$ and CATALIN GEORGE NENCIU ${ }^{1,8}$ \\ Departments of ${ }^{1}$ Obstetrics and Gynecology, ${ }^{2}$ Urology and ${ }^{3}$ Dermatology, 'Carol Davila' University of Medicine \\ and Pharmacy, 050474 Bucharest; ${ }^{4}$ Department of Obstetrics and Gynecology, University Emergency Hospital, \\ 050098 Bucharest; Departments of ${ }^{5}$ Obstetrics and Gynecology, ${ }^{6}$ Dermatology, Elias Emergency University Hospital, \\ 011461 Bucharest; ${ }^{7}$ Department of Urology, 'Prof. Dr. Th. Burghele' Clinical Hospital, 050659 Bucharest; ${ }^{8}$ Department \\ of Obstetrics and Gynecology, 'Sf. Ioan' Clinical Emergency Hospital -'Bucur' Maternity, 040294 Bucharest, Romania
}

Received October 2, 2020; Accepted November 4, 2020

DOI: $10.3892 /$ etm.2021.9709

\begin{abstract}
COVID-19 infection has rapidly become a global issue that has brought essential changes in the daily life of patients and doctors. The pandemic outbreak represents a significant burden on humankind; yet, life still moves on with approximately 350,000 babies being born every day around the world (UNICEF-2018). Some of these mothers will have other conditions, including COVID-19 infection. As healthcare providers, it is our responsibility to treat all women equal no matter what illness they have and to offer them the best possible conditions to give birth vaginally or via Caesarian section, in a safe environment for them and their babies. The main concern is represented by the limitation of the disease transmission to pregnant patients and newborns while managing maternal or fetal emergencies. We have limited information regarding COVID-19 infection, and the data are constantly changing and evolving. New information is brought to light almost on a weekly basis. This review aims to synthesize the recommendations and current experience regarding the birth method for infected women, labor management, Caesarian section management, and breastfeeding indications in these cases.
\end{abstract}

Correspondence to: Dr Florica Sandru, Department of Dermatology, Elias Emergency University Hospital, Mărăști Boulevard, No. 17, 011461 Bucharest, Romania

E-mail: florysandru@yahoo.com

*Contributed equally

Key words: COVID-19, pregnancy, labor, Caesarean section, breastfeeding

\section{Contents}

1. Introduction

2. Research methods

3. Results

4. Discussion

5. Conclusions

\section{Introduction}

Since March 11, when the coronavirus outbreak was declared a pandemic, the medical world has changed, priorities have changed, and both health care professionals and patients must adapt to the new situation. One particular group of patients is represented by pregnant women that cannot choose or postpone the moment and conditions of delivery for them to heave the desired and perfect birth as they previously expected. The primary role of the medical professional is to help them pass this stressful moment in the best manner possible while respecting the protocols. They are protecting the patients from a potential transmission, thus protecting themselves.

Coronavirus SARS-CoV-2 is a new strain of coronavirus first identified in humans in 2019, in a pneumonia case in China that afterward spread to the whole world (1). It was first isolated from three patients, in the bronchoalveolar lavage fluid, and was considered a member of the $\beta$-CoVs (Co-Vs are a class of RNA viruses that can cause respiratory, enteric, hepatic or neurologic diseases) (2). It shares $79.5 \%$ sequence identity to SARS-CoV and 50\% sequence identity to MERS-CoV (3), which permitted evaluation of the outcome of coronavirus spectrum infections during pregnancy and compensates for the lack of knowledge regarding SARS-CoV2 with experience from similar diseases (4). The first article that described a cohort of pregnant patients with confirmed COVID-19 pneumonia was published by Huang et al (5). The authors described the clinical and laboratory characteristics of the disease as well as evolution, treatment, and outcome. Similar to that in the general population, the condition is characterized by fever, 
cough, diarrhea in rare cases, ground-glass opacity on the tomography, and lymphocytopenia (6).

Although initially it was stated that there is no evidence that pregnant women are at higher risk compared to the general population (7), currently as a precaution measure, they are considered at risk of developing severe forms of infection with coronavirus (8). It is a known fact that the changes in immunity during pregnancy predispose women to various diseases. Adding physiological cardiopulmonary adaptation, pregnant patients can develop a more severe form of respiratory infections (6). As mentioned before, the similarities with SARS-CoV and MERS-CoV (that can cause severe complications in pregnant women) suggest an increased risk (6). Overall, even if there is no substantial evidence that indicate pregnancy as a critical risk factor, there is a real need for special attention in this group of patients. An additional concern is represented by the impact of the infection on the fetus or the newborn. There are different recommendations for pregnant women with non-severe disease and those severe and critical cases.

For the patients with non-severe disease, the management is represented by monitoring the fluid and electrolyte balance, monitoring possible bacterial infection, and symptomatic therapy. In this group of patients, antiretroviral treatment can be administrated only upon the virologist indication. Women must be counseled regarding the potential adverse events. Until birth, routine fetal monitoring is indicated (CTG, an ultrasound that evaluates fetal growth, vascular Doppler and amniotic fluid volume) (6). In patients with severe disease, there is a need for more aggressive treatment due to the higher maternal and perinatal mortality rates. The first supporting measures are represented by adequate hydration, oxygen therapy, chest physiotherapy, and placing the patient in a negative-pressure isolation room (9). Antibacterial and antiviral treatment must be initiated upon both virologist and microbiologist recommendations. Careful monitoring of the vital signs must be realized for all patients to manage potential complications promptly. A multidisciplinary team is required for these cases (9). Fetal monitoring will be similar as in non-severe cases.

Regarding the manner of birth, it is considered that COVID-19 infection alone cannot be the primary cause of delivery (10). The mode and the time of delivery must be evaluated for every patient, individually, consulting the multidisciplinary team and assessing the maternal and fetal status (11).

\section{Research methods}

The present study aimed to synthesize the recommendations and current experience regarding the birth method for infected (COVID-19-positive) women, labor management, C-section management and breastfeeding indications. We searched PubMed and the Cochrane database to select the published literature and articles that emerged from the novel coronavirus outbreak. We selected the studies published until April 30, 2020. We found 50 papers searching for 'pregnancy, covid-19, delivery, breastfeeding' as key words. We included only 13 papers that reported the birth method and indications for Caesarian section, neonatal investigations regarding the possibility of transmission and the mother-newborn outcome. We scrutinized the delivery method selection, Cesarean section indications, and maternal and fetal outcomes.

\section{Results}

Our work covers studies from China, Italy, and the United States, concerning women diagnosed with COVID-19 upon admission, pregnant or in the post-partum period. These studies summarized 167 births with 169 newborns. All of the patients were evaluated at the admittance for symptoms specific to coronavirus.

The studies reveal medical information concerning 167 women, with age ranging from 20 to 44 years (mean age 30 ), covering almost all of the fertility period. Similar to the general population, clinical manifestations of the SARS-CoV2 infection varied from asymptomatic to severe (Table I). Fever was the most common symptom reported, found in 115 patients $(68.86 \%)$. It was present before admission or beginning of labor $71.3 \%$, and in $28.7 \%$ during birth or in the post-partum period. Cough, dyspnea, myalgia and diarrhea were the infection's symptoms. All patients underwent thoracic computed tomography or chest X-ray. Ground-glass opacity, reticular interstitial opacities, and other evidence of pneumonia were observed in one or both lungs. A total of 105 patients (62.87\%) were certified with pneumonia. Blood work revealed leukocytosis with lymphopenia and high RPC. The most common comorbidities encountered in these patients were represented by obesity, diabetes, and hypertension. Of all patients, 9 women $(5.4 \%$ of cases) needed medical supervision in the intensive care unit (ICU). One patient required admission in the ICU for multiple organ dysfunction, ARDS, acute hepatic and renal failure and septic shock, 1 for renal insufficiency, and 5 for respiratory distress. All patients received supportive therapy, antibiotics, or antiviral therapy depending on the severity of the infection and the clinical protocols. The majority were diagnosed with COVID-19 disease upon admission. Some were admitted directly to the delivery room, as for others, the symptomatology surfaced post-partum. A group of comorbidities was prevalent, including obesity, asthma, diabetes mellitus, chronic hypertension and hypothyroidism. Diabetes mellitus was most frequently reported in all articles (5/8).

Maternal features are summarized in Table II. One hundred and thirteen $(67.66 \%)$ patients underwent Cesarian section and $54(32.34 \%)$ delivered vaginally. Cesarian section was prevalent ( $7 / 9$ women) in patients that received medical care in the ICU. The majority of patients diagnosed with pneumonia gave birth through Cesarian section (only 11/92 patients delivered vaginally). These data are obtained from 9 studies; the correlation is not available for all the reviews. COVID-19 pneumonia was the decisive reason for Cesarian section in some studies $(16,23,24)$. Still, different obstetrical pathology was also involved in some cases: 6 with a history of Cesarian section, 12 premature rupture of the membrane, 2 pre-eclampsia, 14 fetal distress, 2 stillbirths or history of stillbirth, 3 abnormal labor (failed induction, the arrest of descent or dilatation), 3 placenta praevia, 2 abnormal umbilical cord, 1 elevated liver enzyme, 1 placentae abruption and 8 not explicitly explained.

A total of 103 women delivered at term, and 25 were preterm births before 34 weeks. The mean gestational age 


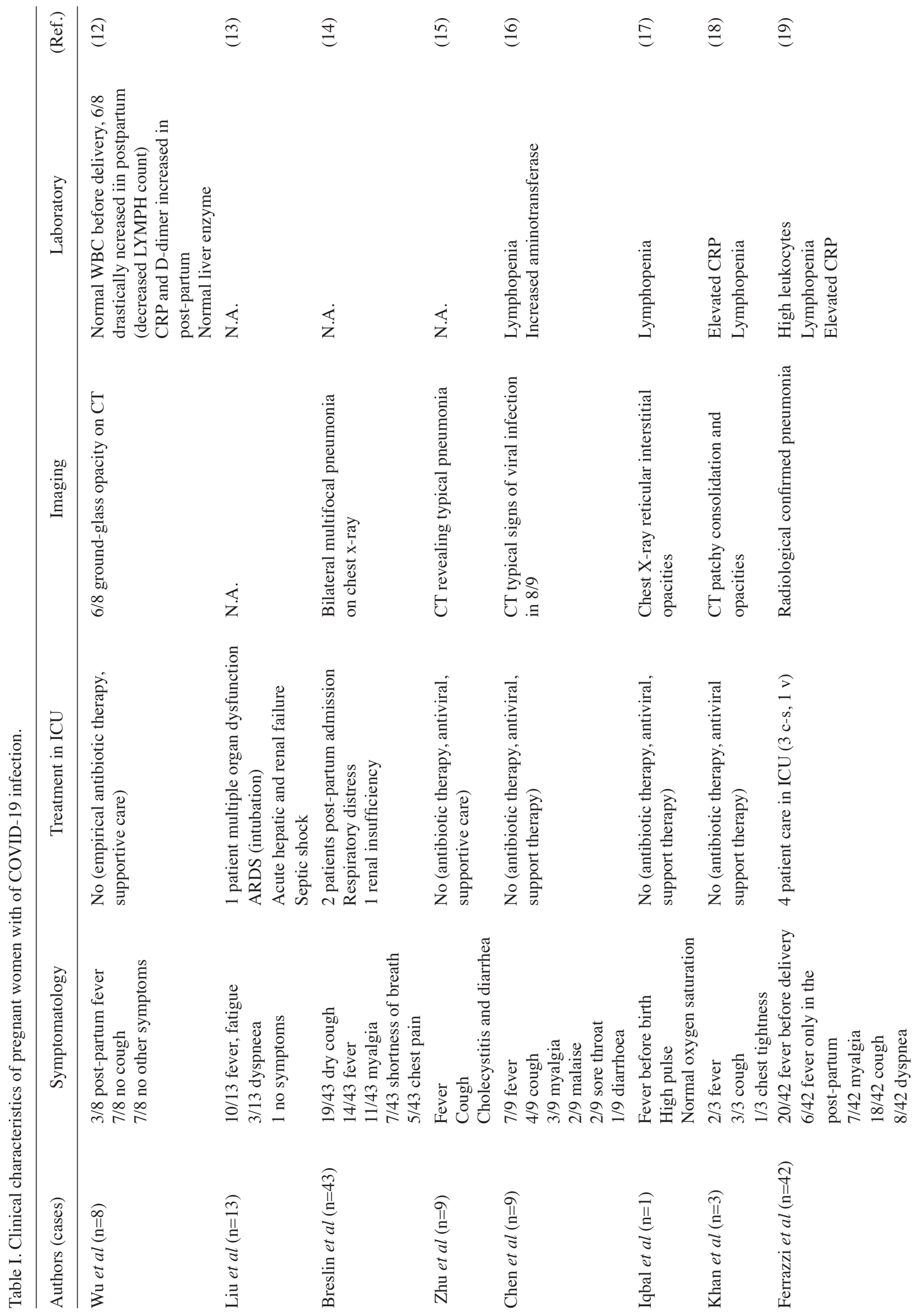




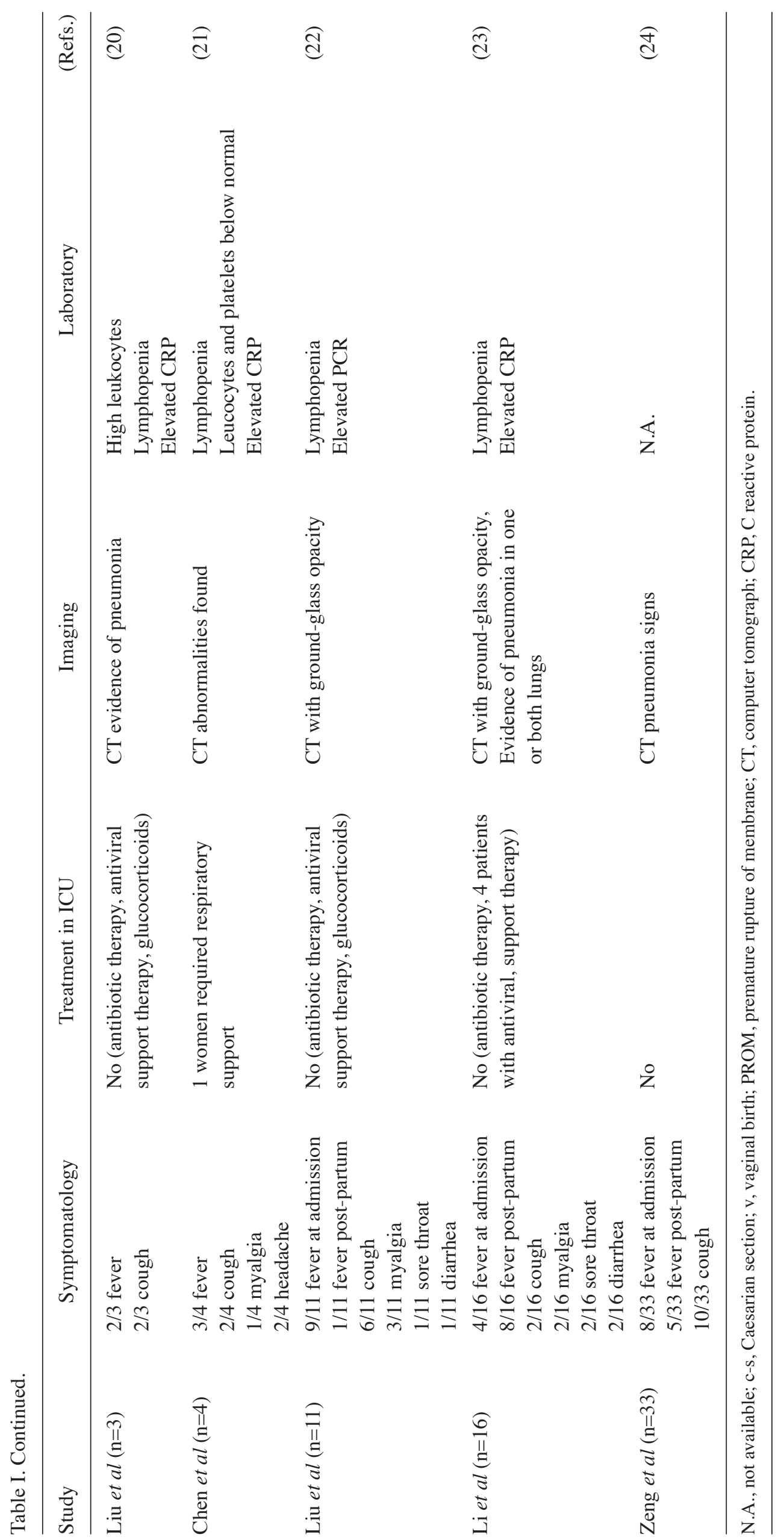




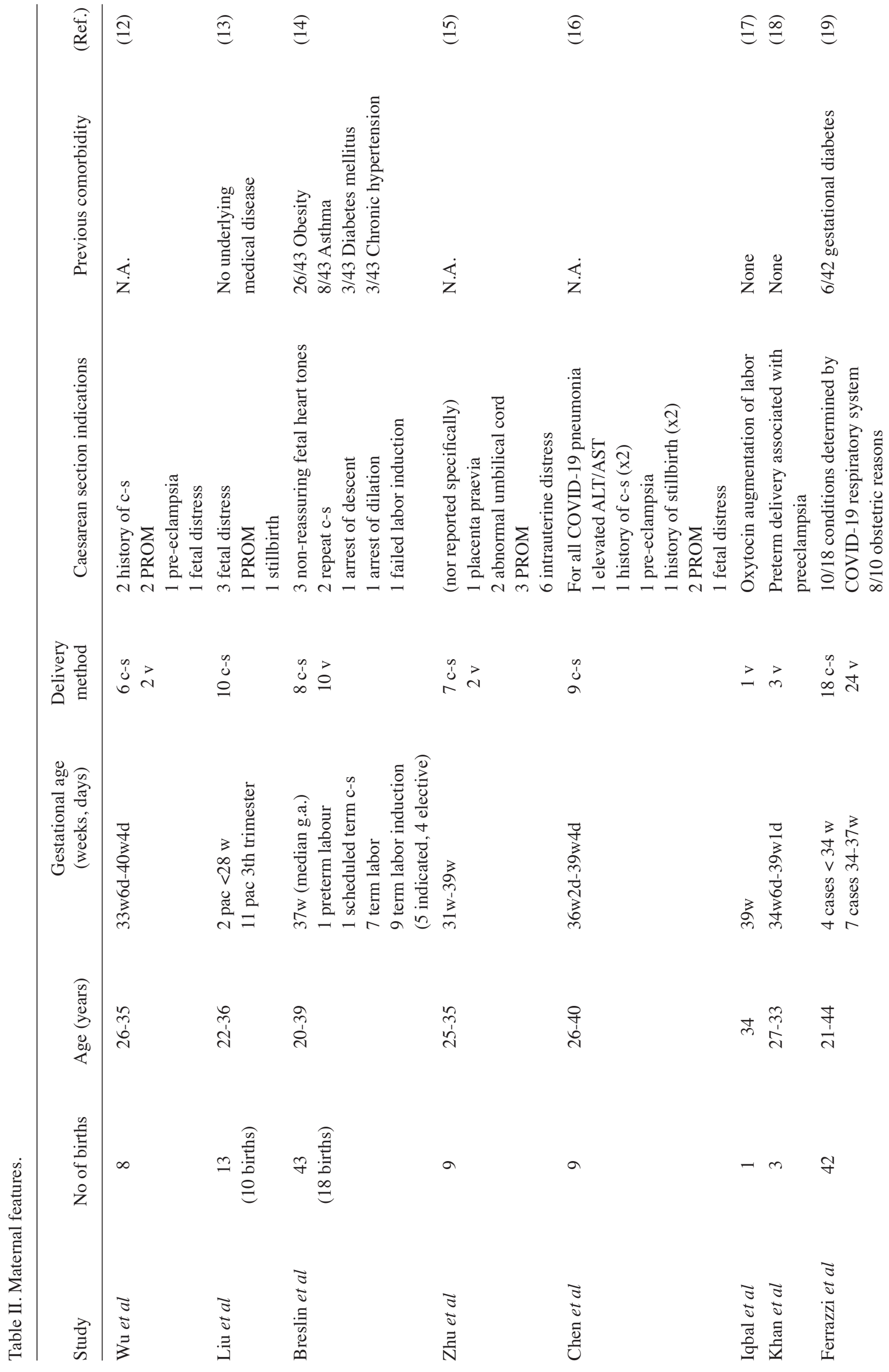




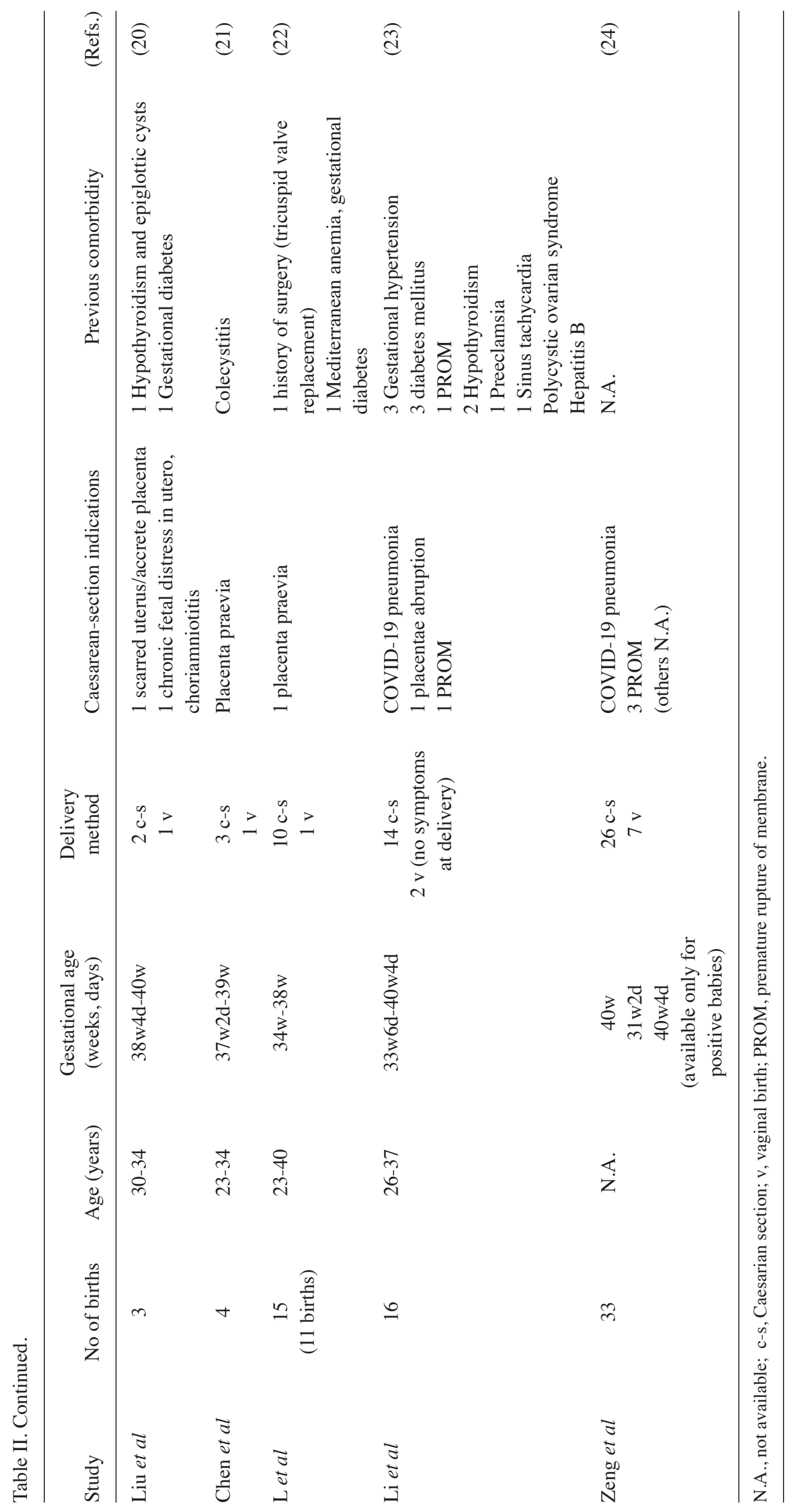


Table III. Characteristics of the newborns.

\begin{tabular}{|c|c|c|c|c|}
\hline Study & Fetal outcome & Congenital transmission & Neonatal care & (Ref.) \\
\hline $\begin{array}{l}\text { Wu et al }(\mathrm{n}=8) \\
(\mathrm{n}=8)\end{array}$ & N.A. & N.A. & N.A. & $(12)$ \\
\hline Liu et al $(\mathrm{n}=10)$ & $\begin{array}{l}1 \text { stillbirth } \\
9 \text { babies with Apgar } \\
10 \text { at } 1 \text { min }\end{array}$ & $\begin{array}{l}\text { No clinical or serological } \\
\text { evidence of transmission }\end{array}$ & N.A. & $(13)$ \\
\hline Breslin et al $(\mathrm{n}=18)$ & $\begin{array}{l}\text { Apgar score } \geq 7 \text { at } 1 \mathrm{~min} \\
\text { Apgar score } \geq 9 \text { at } 5 \mathrm{~min}\end{array}$ & $\begin{array}{l}15 \text { negative on day of life } 0 \\
2 \text { unclear result and repeated } \\
\text { after } 1-2 \text { days } \\
1 \text { indeterminant result } \\
\text { (presumptive negative) }\end{array}$ & $\begin{array}{l}\text { Healthy newborns roomed in } \\
\text { with mothers in isolettes or } \\
\text { in isolated nursery for babies } \\
\text { Breastfeeding was encouraged } \\
\text { (maternal mask usage, hand } \\
\text { hygiene) }\end{array}$ & (14) \\
\hline $\begin{array}{l}\text { Zhu et al } \\
\text { ( } \mathrm{n}=10 \text {, one pair } \\
\text { of twins) }\end{array}$ & $\begin{array}{l}\text { Apgar score } \geq 7 \text { at } 1 \mathrm{~min} \\
\text { Apgar score } \geq 8 \text { at } 5 \mathrm{~min} \\
\text { (1 deceased-thrombocytopenia, } \\
\text { altered liver function) }\end{array}$ & $\begin{array}{l}\text { No transmission } \\
\text { Negative results }\end{array}$ & $\begin{array}{l}\text { Neonatal isolation if there are } \\
\text { high-risk factors }\end{array}$ & $(15)$ \\
\hline Chen et al $(\mathrm{n}=9)$ & $\begin{array}{l}\text { Apgar score } \geq 8 \text { at } 1 \mathrm{~min} \\
\text { Apgar score } \geq 9 \text { at } 5 \mathrm{~min}\end{array}$ & Negative results & $\begin{array}{l}\text { Breastmilk samples from } \\
6 \text { patients were tested, all } \\
\text { negative for SARS-CoV2 }\end{array}$ & $(16)$ \\
\hline Iqbal et al $(\mathrm{n}=1)$ & $\begin{array}{l}\text { Apgar score }=8 \text { at } 1 \mathrm{~min} \\
\text { Apgar score }=9 \text { at } 5 \mathrm{~min}\end{array}$ & Negative results & $\begin{array}{l}\text { No delayed cord clamping or } \\
\text { skin to skin } \\
\text { Radiant warmer bed } \\
\text { Separate room once } \\
\text { The condition was stabilized } \\
\text { Formula and expressed } \\
\text { breast milk }\end{array}$ & (17) \\
\hline Khan et al $(\mathrm{n}=3)$ & $\begin{array}{l}\text { Apgar score } \geq 8 \text { at } 1 \mathrm{~min} \\
\text { Apgar score } \geq 9 \text { at } 5 \mathrm{~min}\end{array}$ & Negative results & Neonatal ward care & $(18)$ \\
\hline Ferrazzi et al $(\mathrm{n}=42)$ & $\begin{array}{l}2 \text { preterm babies with } \\
\text { Apgar }<7 \text { at } 5 \mathrm{~min}\end{array}$ & $\begin{array}{l}2 \text { positive tests in day } 1 \text { and } 3 \\
\text { after contact to mother without } \\
\text { mask (diagnosed in post-partum) } \\
1 \text { case new-born from infected } \\
\text { mother (separated after birth)- } \\
\text { initial test doubtful, positive day } 3\end{array}$ & $\begin{array}{l}10 \text { cases-breastfeeding } \\
\text { allowed with mask }\end{array}$ & (19) \\
\hline Liu et al $(\mathrm{n}=3)$ & $\begin{array}{l}\text { Apgar score }=8 \text { at } 1 \mathrm{~min} \\
\text { Apgar score }=9 \text { at } 5 \mathrm{~min}\end{array}$ & No transmission & Newborns in infant wards & $(20)$ \\
\hline Chen et al $(\mathrm{n}=4)$ & $\begin{array}{l}\text { Apgar score } \geq 7 \text { at } 1 \mathrm{~min} \\
\text { Apgar score } \geq 8 \text { at } 5 \mathrm{~min}\end{array}$ & $\begin{array}{l}\text { No transmission } \\
3 \text { negative results } \\
1 \text { baby's parents did not provide } \\
\text { consent }\end{array}$ & $\begin{array}{l}\text { Separated from mother } \\
\text { Formula feed }\end{array}$ & $(21)$ \\
\hline Liu et al $(\mathrm{n}=11)$ & $\begin{array}{l}\text { Apgar score }=8 \text { at } 1 \mathrm{~min} \\
\text { Apgar score }=9 \text { at } 5 \mathrm{~min}\end{array}$ & N.A. & N.A. & $(22)$ \\
\hline $\begin{array}{l}\text { Li et al }(\mathrm{n}=17, \\
\text { one pair of twins })\end{array}$ & $\begin{array}{l}\text { Apgar score } 9.6 \pm 0.5 \text { at } 1 \mathrm{~min} \\
\text { Apgar score } 10 \text { at } 5 \mathrm{~min}\end{array}$ & 3 tested negative for SARS-CoV-2 & $\begin{array}{l}\text { Newborns in infant wards } \\
\text { Other family members took } \\
\text { care of the baby }\end{array}$ & $(23)$ \\
\hline Zeng et al $(\mathrm{n}=33)$ & $\begin{array}{l}\text { Available only for the } \\
\text { premature positive baby } \\
\text { Apgar scores were } 3,4 \text {, and } \\
5 \text { at } 1,5 \text {, and } 10 \text { min after birth }\end{array}$ & $\begin{array}{l}30 \text { negative test } \\
3 \text { positive test } \\
\text { The vertical maternal-fetal } \\
\text { transmission cannot be ruled out } \\
\text { in the current cohort } \\
\text { Amniotic fluid, cord blood, and } \\
\text { breast milk were negative for } \\
\text { SARS-CoV-2 }\end{array}$ & $\begin{array}{l}\text { N.A. } \\
\text { The authors mention that } \\
\text { the ill neonate may have } \\
\text { been symptomatic from } \\
\text { prematurity, asphyxia, } \\
\text { and sepsis, rather than } \\
\text { SARS-CoV-2 infection }\end{array}$ & (24) \\
\hline
\end{tabular}

N.A., not available; c-s, Caesarian section; v, vaginal birth; PROM, premature rupture of membrane. 
upon delivery was 38 weeks. One stillbirth and one neonatal death upon thrombocytopenia and altered liver function were reported. The Apgar score was in all studies greater than seven at $1 \mathrm{~min}$ and eight at $5 \mathrm{~min}$, except for a few cases. Three preterm babies had Apgar scores under seven at 5 min. One study (24) suggests that the neonatal status may have been influenced by prematurity, asphyxia, and sepsis, rather than SARS-CoV-2 infection. The neonatal infection is the consequence of the vertical transmission from mother to fetus, close contact to positive mother or family visitors, or hospital-acquired (25). Samples were taken from amniotic fluid, cord blood, breastmilk, and a swab from the baby's throat, to evaluate the congenital infection with SARS-CoV2. The majority of the published studies claimed that transmission is not precise but suggested that further evaluation must be considered. Few cases must be mentioned: 2 unclear results, repeated after 1-2 days and turned negative, 1 indeterminant result (presumptive negative) (14), 2 positive tests for one newborn in day 1 and 3 after direct contact with the mother without mask (maternal infection diagnosed in post-partum), 1 newborn from infected mother (separated from her after birth) with initial test doubtful and positive day third (19) and 3 positive newborns, in which the authors couldn't rule out the vertical maternal-fetal transmission (24). A total of 5 cases from 169 newborns with positive results for SARS-CoV2 were reported $(2.95 \%)$. The majority of children were separated from their mothers and were cared for and monitore in the neonatal ward. One study mentioned that breastfeeding was permitted for the mother with a mask in 10 cases (19). The same survey reports skin-to-skin contact in the neonate diagnosed in the post-partum period (19). The baby later also tested positive. It is considered that the mother to infant transmission is more likely to be realized through direct contact, the same as in the general population. Characteristics of the newborns are presented in Table III.

\section{Discussion}

Giving birth must be a fulfilling moment in every woman's life. This pandemic infection is a reality that cannot be denied. This is the reality that we currently face. We should not neglect one to the detriment of the other. The birth method can be more restrictive in these situations, and also the direct contact of the newborn with the mother and other close family members should be delayed. The restricted direct contact can be the leading cause of the weak connection between mother and baby, low lactation rates, and post-partum depression rise. At the same time, as the personnel offers adequate treatment for both mother and newborn, there should also be consideration and means that can conserve breastfeeding, increase mother-baby bonding and sustain the birth method chosen by the mother. Any action should be initiated in a safe environment and adequate equipment for patients and medical staff.

As for the method of delivery, it is recommended that severe and critical cases be finalized through surgery. In mild cases with proper evolution of travail, vaginal delivery can be indicated (25), recommending to shorten the second stage of labor (26). For the moment separating the mother from the child is determined to be the safe way to protect the newborn from an infected mother. Breastfeeding directly can favor virus transmission, as rooming-in service for the baby demands designated personnel to supervise. Even in this situation, stimulating the lactation onset and offering the mother's milk to the baby must be considered in most of the cases, as it can provide specific antibodies (27).

Davanzo et al (26) consider that mothers should be sustained to provide milk for their infants, as it is not clear that breastmilk is a pathway for the virus. If the mother is asymptomatic or paucisymptomatic, the dyad should be cared for together, to stimulate breastfeeding and facilitate their interaction.

Even if information concerning this type of infection is elucidate after a long time period, the novelty of this particular type is a challenge for the health care system and especially for the obstetricians that need to balance the management of the mother-fetal dyad (28). As in previous outbreaks with SARS or MERS, vaccine research was initiated, but there were limited results (29). The disease and potential vaccine impact on the general society, on fertility outcome and in pregnant women are yet to be seen.

\section{Conclusion}

For now, small-scale conclusions can be drawn. Cesarean section is the prevailing method to deliver in the context of SARS-CoV2 pregnancy infection. Outcomes from 167 births are encouraging, as only five newborns out of 169 tested positive. A multidisciplinary team must take care of the mother and the infant to obtain the best results. Further investigations are necessary, as the pandemic has not yet reached its end, to assess the vertical transmission and also the advantages and disadvantages for each delivery method, rooming-in, and breastfeeding in patients with SARS-CoV2.

\section{Acknowledgements}

Not applicable.

\section{Funding}

No funding was received.

\section{Availability of data and materials}

Further information concerning this Review is available from the Corresponding author.

\section{Authors' contributions}

MCD, CGN and FS designed the review. MMC, AEN, AP and $\mathrm{RCP}$ researched the literature and drafted the manuscript. MCD, MMC, AEN, CGN and FS substantially contributed to the conception of the work, revised and edited the final manuscript. All authors read and approved the final version of the manuscript.

\section{Ethics approval and consent to participate}

Not applicable. 


\section{Patient consent for publication}

Not applicable.

\section{Competing interests}

The authors declare that they have no competing interests.

\section{References}

1. Timeline of WHO's response to COVID-19 https://www.who.int/ news/item/29-06-2020-covidtimeline.

2. Jin Y, Yang H, Ji W, Wu W, Chen S, Zhang W and Duan G: Virology, epidemiology, pathogenesis, and control of COVID-19. Viruses 12: 372, 2020.

3. Lu R, Zhao X, Li J, Niu P, Yang B, Wu H, Wang W, Song H, Huang B, Zhu N, et al: Genomic characterisation and epidemiology of 2019 novel coronavirus: Implications for virus origins and receptor binding. Lancet 395: 565-574, 2020.

4. Di Mascio D, Khalil A, Saccone G, Rizzo G, Buca D, Liberati M, Vecchiet J, Nappi L, Scambia G, Berghella V and D'Antonio F: Outcome of coronavirus spectrum infections (SARS, MERS COVID-19) during pregnancy: A systematic review and meta-analysis. Am J Obstet Gynecol MFM 2: 100107, 2020.

5. Huang C, Wang Y, Li X, Ren L, Zhao J, Hu Y, Zhang L, Fan G, $\mathrm{Xu}$ J, Gu X, et al: Clinical features of patients infected with 2019 novel coronavirus in Wuhan, China. Lancet 395: 497-506, 2020.

6. Poon LC, Yang H, Lee JCS, Copel JA, Leung TY, Zhang Y, Chen D and Prefumo F: ISUOG interim guidance on 2019 novel coronavirus infection during pregnancy and puerperium: Information for healthcare professionals. Ultrasound Obstet Gynecol 55: 700-708, 2020.

7. World Health Organization. Coronavirus disease (COVID-19): Pregnancy and childbirth 2 September 2020 | Q\&A. https:// www.who.int/news-room/q-a-detail/coronavirus-disease-covid19-pregnancy-and-childbirth .

8. Royall College of Obstetricians and Gynecologists - Coronavirus (COVID-19) Infection in Pregnancy https://www.rcog.org. uk/globalassets/documents/guidelines/2020-10-14-coronavirus-covid-19-infection-in-pregnancy-v12.pdf .

9. Rasmussen SA, Smulian JC, Lednicky JA, Wen TS and Jamieson DJ: Coronavirus disease 2019 (COVID-19) and pregnancy: What obstetricians need to know. Am J Obstet Gynecol 222: 415-426, 2020.

10. Centers for Disease Control and Prevention. Operational Considerations for Maintaining Essential Services for and Providing Maternal, Newborn, and Child Healthcare in Low-Resource Countries Updated July 27, 2020. https://www. cdc.gov/coronavirus/2019-ncov/global-covid-19/pregnant.html.

11. Qi H, Chen D, Feng L, Zou L and Li J: Obstetric considerations on delivery issues for pregnant women with COVID-19 infection. Chin J Obstet Gynecol 55: E001, 2020.

12. Wu C, Yang W, Wu X, Zhang T,Zhao Y, Ren W and Xia J: Clinical manifestation and laboratory characteristics of SARS-CoV-2 infection in pregnant women. Virol Sin 35: 305-310, 2020.

13. Liu $\mathrm{Y}$, Chen $\mathrm{H}$, Tang $\mathrm{K}$ and Guo $\mathrm{Y}$ : Clinical manifestations and outcome of SARS-CoV-2 infection during pregnancy. J Infect, March 4, 2020 (Online ahead of print).

14. Breslin N, Baptiste C, Gyamfi-Bannerman C, Miller R, Martinez R, Bernstein K, Ring L, Landau R, Purisch S, Friedman AM, et al: COVID-19 infection among asymptomatic and symptomatic pregnant women: Two weeks of confirmed presentations to an affiliated pair of New York City hospitals. Am J Obstet Gynecol MFM 2: 100118, 2020.
15. Zhu H, Wang L, Fang C, Peng S, Zhang L, Chang G, Xia S and Zhou W: Clinical analysis of 10 neonates born to mothers with 2019-nCoV pneumonia. Transl Pediatr 9: 51-60, 2020.

16. Chen H, Guo J, Wang C, Luo F, Yu X, Zhang W, Li J, Zhao D, $\mathrm{Xu}$ D, Gong Q, et al: Clinical characteristics and intrauterine vertical transmission potential of COVID-19 infection in nine pregnant women: A retrospective review of medical records. Lancet 395: 809-815, 2020.

17. Iqbal SN, Overcash R, Mokhtari N, Saeed H, Gold S, Auguste T, Mirza MU, Ruiz ME, Chahine JJ, Waga M and Wortmann G: An uncomplicated delivery in a patient with Covid-19 in the United States. N Engl J Med 382: e34, 2020.

18. Khan S, Peng L, Siddique R, Nabi G, Nawsherwan, Xue M, Liu J and Han G: Impact of COVID-19 infection on pregnancy outcomes and the risk of maternal-to-neonatal intrapartum transmission of COVID-19 during natural birth. Infect Control Hosp Epidemiol 41: 748-750, 2020.

19. Ferrazzi E, Frigerio L, Savasi V, Vergani P, Prefumo F, Barresi S, Bianchi S, Ciriello E, Facchinetti F, Gervasi MT, et al: Vaginal delivery in SARS-CoV-2-infected pregnant women in Northern Italy: A retrospective analysis. BJOG, April 27, 2020 (Online ahead of print). DOI: $10.1111 / 1471-0528.16278$.

20. Liu W, Wang Q, Zhang Q, Chen L, Chen J, Zhang B, Lu Y, Wang S, Xia L, Huang L, et al: Coronavirus disease 2019 (COVID-19) during pregnancy: A case series. Preprints: $2020020373,2020$.

21. Chen Y, Peng H, Wang L, Zhao Y, Zeng L, Gao H and Liu Y: Infants born to mothers with a new coronavirus (COVID-19). Front Pediatr 8: 104, 2020.

22. Liu D, Li L, Wu X, Zheng D, Wang J, Yang L and Zheng C: Pregnancy and perinatal outcomes of women with coronavirus disease (COVID-19) pneumonia: A preliminary analysis. AJR Am J Roentgenol 215: 127-132, 2020.

23. Li N, Han L, Peng M, Lv Y, Ouyang Y, Liu K, Yue L, Li Q, Sun G, Chen L and Yang L: Maternal and neonatal outcomes of pregnant women with COVID-19 pneumonia: A case-control study. Clin Infect Dis, March 30, 2020 (Online ahead of print).

24. Zeng L, Xia S, Yuan W, Yan K, Xiao F, Shao J and Zhou W: Neonatal early-onset infection with SARS-CoV-2 in 33 neonates born to mothers with COVID-19 in Wuhan, China. JAMA Pediatr 174: 722-725, 2020.

25. Wang SS, Zhou X, Lin XG, Liu YY, Wu JL, Sharifu LM, Hu XL, Rong ZH, Liu W, Luo XP, et al: Experience of clinical management for pregnant women and newborns with novel coronavirus pneumonia in Tongji Hospital, China. Curr Med Sci 40: 285-289, 2020.

26. Davanzo R, Moro G, Sandri F, Agosti M, Moretti C and Mosca F: Breastfeeding and Coronavirus Disease-2019. Ad interim indications of the Italian society of neonatology endorsed by the union of European neonatal \& perinatal societies. Matern Child Nutr 16: e13010, 2020.

27. Yang $\mathrm{H}$, Wang $\mathrm{C}$ and Poon LC: Novel coronavirus infection and pregnancy. Ultrasound Obstet Gynecol 55: 435-437, 2020

28. Docea AO, Tsatsakis A, Albulescu D, Cristea O, Zlatian O, Vinceti M, Moschos SA, Tsoukalas D, Goumenou M, Drakoulis N,et al: A new threat from an old enemy: Re-emergence of coronavirus (Review). Int J Mol Med 45: 1631-1643, 2020.

29. Calina D, Docea AO, Petrakis D, Egorov AM, Ishmukhametov AA, Gabibov AG, Shtilman MI, Kostoff R, Carvalho F, Vinceti M, et al: Towards effective COVID-19 vaccines: Updates, perspectives and challenges (Review). Int J Mol Med 46: 3-16, 2020. 